\title{
Phenethyl Esters and Amide of Ferulic Acid, Hydroferulic Acid, Homovanillic Acid, and Vanillic Acid: Synthesis, Free Radicals Scavenging Activity, and Molecular Modeling as Potential Cholinesterases Inhibitors
}

\author{
Ayyoub Selka, Fanta J. Ndongou Moutombi, Marc Cormier and Mohamed Touaibia * \\ Department of Chemistry and Biochemistry, Université de Moncton, Moncton, NB E1A 3E9, Canada; \\ ayyoub.selka@hotmail.fr (A.S.); fanta.ndongou.moutombi@umoncton.ca (F.J.N.M.); \\ marc.cormier@umoncton.ca (M.C.) \\ * Correspondence: mohamed.touaibia@umoncton.ca
}

Received: 17 July 2020; Accepted: 5 August 2020; Published: 9 August 2020

\begin{abstract}
As ferulic acid was reported to be involved in novel potential mechanisms associated with Alzheimer's disease (AD) therapy, five closely related phenethyl esters and amide of this natural product were synthesized and screened for their free radicals scavenging activity. Ferulic acid and its analogue's absorption, distribution, metabolism, and excretion (ADME) properties were predicted. All compounds obey Lipinski's rules. Moreover, all evaluated compounds seem to present a high oral bioavailability and blood-brain barrier (BBB) permeation which is crucial for Alzheimer's disease drug candidates. Molecular docking of analogues 4 and 8 with acetylcholinesterase (AChE) and butyrylcholinesterase (BChE) showed interactions with the residues of the catalytic triad of AChE and $B C h E$. In addition to their interactions with the anionic subsite, hydroferulic acid phenethyl ester 4 and homovanillic acid phenethyl ester 8 may have potential as inhibitors of $\mathrm{AChE}$ and $\mathrm{BChE}$, respectively.
\end{abstract}

Keywords: ferulic acid; phenethyl esters; Alzheimer's disease; cholinesterases; radicals scavenging; molecular docking

\section{Introduction}

Alzheimer's disease (AD), a chronic neurodegenerative disorder characterized by cognitive impairment, is among the most common causes of dementia affecting 5.8 million people in 2019 [1], and it is estimated that this number will be more than triple by 2050 [2]. One of the most recurrent pathologic hallmarks of Alzheimer's disease is the formation of $\beta$-amyloid $(\beta A)$ aggregation $[3,4]$. The latter induces oxidative stress through the production of superoxide, hydrogen peroxide, and lipid peroxide in the brain [5]. In addition, $\beta$ A aggregation has been reported to induce inflammation in the brain through the production of proinflammatory cytokines [5].

Acetylcholinesterase $(\mathrm{AChE})$ and butyrylcholinesterase $(\mathrm{BChE})$ are key enzymes in the degradation of the neurotransmitter acetylcholine, accelerating $\beta$ A aggregation [6]. Therefore, those enzymes become one of the major targets in the AD therapy [3]. As acetylcholinesterase inhibitors, tacrine, donepezil, rivastigmine, and galantamine are among the only five prescription drugs currently approved to treat AD symptoms. However, these drugs do not stop or reverse the progression of the disease proving the need for new molecules and approaches [7]. Furthermore, the last decades witnessed the development of more than 50 drug candidates for $\mathrm{AD}$, although none of them were able to surpass phase III clinical trials [8]. 
Many antioxidant compounds, such as ferulic acid (FA (1); Figure 1), have been demonstrated to protect the brain from $\beta$ A neurotoxicity $[9,10]$. On the other hand, long-term administration of FA, which is founded in many grains and vegetables [11], protects mice against $\beta \mathrm{A}$-induced learning and memory deficits in in vivo studies [12].<smiles>COc1cc(/C=C/C(=O)O)ccc1O</smiles>

Ferulic acid (FA) 1<smiles>O=C(/C=C/c1ccc(O)c(O)c1)OCCc1ccccc1</smiles>

Caffeic acid phenethyl ester (CAPE) 2

Figure 1. Structure of ferulic acid (FA) 1 and caffeic acid phenethyl ester (CAPE) 2.

Continuing our interest in phenolic acids and their derivatives in inflammation, we were interested in FA ((4-hydroxy-3-methoxycinnamic acid (1)), closely related analogues in the context of Alzheimer's disease, by analogy with caffeic acid phenethyl ester (CAPE (2); Figure 1), which has demonstrated effects on AD [4,13] phenethyl ester of FA (1) has been synthesized. For comparison, amide analogue, as well as corresponding propanoic, acetic, and benzoic acid esters were synthesized and tested for their free radical scavenging activity. Absorption, distribution, metabolism and excretion (ADME) properties of all compounds were calculated and compared with those of FA (1). Molecular docking was performed with several crystallized AChE proteins for comparison. As a recent study demonstrated, the accumulation of $\mathrm{A} \beta$ plaque during $\mathrm{AD}$ is associated with the presence of $\mathrm{BChE}$ [14]. Docking was performed with selected crystallized BChE proteins.

\section{Results}

\subsection{Synthesis}

To prepare analogue 3, ferulic acid was esterified by reacting with phenethyl bromide in the presence of sodium carbonate and potassium iodide as a catalyst. Ester analogue was thus obtained in a single step with high yield (Scheme 1). In view of the toxicity of hexamethylphosphoric acid triamide (HMPA), we elected to use the common alternative dimethyl sulfoxide (DMSO) as the medium for this single-step esterification. The results were very conclusive since the reaction gave good yields.<smiles>CC#CC(=O)OCCc1ccccc1</smiles>

Scheme 1. (i) $\mathrm{Na}_{2} \mathrm{CO}_{3}, \mathrm{PhCH}_{2} \mathrm{CH}_{2} \mathrm{Br}$, KI, DMSO, $0{ }^{\circ} \mathrm{C}$ to rt, 24 h. (ii) $\mathrm{Et}_{3} \mathrm{~N}, \mathrm{BOP}, \mathrm{PhCH}_{2} \mathrm{CH}_{2} \mathrm{NH}_{2}$, $\mathrm{CH}_{2} \mathrm{Cl}_{2}, \mathrm{rt}, 16$ h. (iii) $10 \% \mathrm{Pd} / \mathrm{C}, \mathrm{H}_{2}, \mathrm{MeOH}, \mathrm{rt}, 16 \mathrm{~h}$.

The reduced analogue 4, which could be prepared by a Mitsonobu reaction [15], was prepared by a catalytic hydrogenation in the presence of $\mathrm{Pd} / \mathrm{C}$ as shown in Scheme 1 . For comparison, the amide analogue 5 was synthesized via peptide coupling with 
benzotriazol-1-yloxy)tris(dimethylamino)phosphonium hexafluorophosphate (BOP) as a coupling agent as described by Zhi-Hao et al. [16].

Instead of using a Mitsonobu reaction to obtain benzoic and acetic analogues as described by Appendino et al. [15], the single step esterification of homovanilic acid (6) and vanilic acid (7) with phenethyl bromide allowed us to obtain the two corresponding phenethyl esters $\mathbf{8}$ and $\mathbf{9}$ in good yields (Scheme 2).

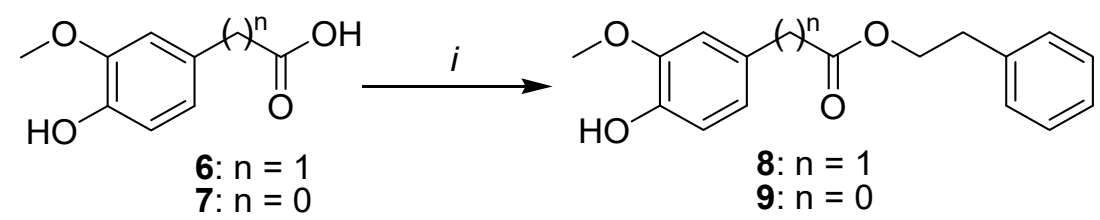

Scheme 2. (i) $\mathrm{Na}_{2} \mathrm{CO}_{3}, \mathrm{PhCH}_{2} \mathrm{CH}_{2} \mathrm{Br}, \mathrm{KI}, \mathrm{DMSO}, 0^{\circ} \mathrm{C}$ to $\mathrm{rt}, 24 \mathrm{~h}$.

\subsection{Free Radical Scavenging Activity Assay}

Free radical scavenging activity by its inhibition of hydrogen superoxide was considered as prominent strategy for AD therapy [3,17]. Therefore, radical scavenging activities of FA (1) and its related analogues were assayed using 2,2-Diphenyl-1-picrylhydrazyl (DPPH) as a stable radical and are expressed as $\mathrm{IC}_{50}$ concentrations in Table 1 . Ascorbic acid was used as positive control.

Table 1. Free radical scavenging activity.

\begin{tabular}{cc}
\hline Compounds & IC $_{\mathbf{5 0}}(\boldsymbol{\mu M})[$ SEM] \\
\hline FA $(\mathbf{1})$ & $23.93 \pm 0.09$ \\
$\mathbf{3}$ & $49.99 \pm 0.04$ \\
$\mathbf{4}$ & $39.41 \pm 0.06$ \\
$\mathbf{5}$ & $40.00 \pm 0.07$ \\
$\mathbf{8}$ & $53.63 \pm 0.06$ \\
$\mathbf{9}$ & $27.95 \pm 0.18$ \\
ascorbic acid & $12.68 \pm 0.02$ \\
\hline
\end{tabular}

Belonging to the phenolic family known for their free radical scavenging potential, the synthesized derivatives show good activity compared to the positive control (Ascorbic acid: $\mathrm{IC}_{50}=12.68 \mu \mathrm{M}$ ) and FA $(\mathbf{1})\left(\mathrm{IC}_{50}=23.93 \mu \mathrm{M}\right)$. The esterification and the amidation of FA $(\mathbf{1})$ reduce its free radical scavenging activity as shown with analogues 3 and 4 . Compared to analogue 3 , reduced analogue 4 and amide 5 were more active. Among the tested compounds, vanilic acid derivative 9 was the most active with an $\mathrm{IC}_{50}$ value of $27.95 \mu \mathrm{M}$. The direct attachment of the carbonyl group on the catechol ring seems to increase the radical scavenging activity. Vanilic acid phenethylester 9, whose carbonyl group is directly linked to the aromatic ring, has the highest free radical scavenging activity $\left(\mathrm{IC}_{50}=27.95 \mu \mathrm{M}\right)$ of all the tested compounds. By comparison, homovanilic acid phenethylester 8, whose carbonyl was moved one carbon away from the aromatic ring, was less potent $\left(\mathrm{IC}_{50}=53.6 \mu \mathrm{M}\right)$. A further increase to two carbon atoms away from the aromatic ring does not have as great an effect (analogue (4): $\left.\mathrm{IC}_{50}=39.4 \mu \mathrm{M}\right)$.

\subsection{In Silico Physicochemical Properties and Drug Likeness Evaluation}

ADME properties of FA (1) acid and its related analogues were predicted using the web tool SwissADME (http://www.swissadme.ch). Bearing low hydrogen bond donors and acceptors, rotatable bonds as well as molecular weight, all synthesized compounds follow the Lipinski's rules (Table 2). Moreover, the pharmacokinetics properties are interesting, such as gastrointestinal absorption and, more significantly, the blood-brain barrier (BBB) permeation, which is crucial for drug candidates targeting the central nervous system as is the case for AD therapies. In addition, the lipophilicity 
profile as CLog P and topological polar surface area (TPSA) are also crucial for drug penetration and delivery. All synthesized compounds show significant values, with CLog P $<5$ as well as $<140 \AA$ for TPSA, which tends to have higher oral bioavailability.

Table 2. Absorption, distribution, metabolism, and excretion (ADME) profile of FA (1) acid and its related analogues.

\begin{tabular}{|c|c|c|c|c|c|c|c|c|}
\hline & \multicolumn{4}{|c|}{ Physicochemical Properties } & \multicolumn{2}{|c|}{ Lipophilicity } & \multicolumn{2}{|c|}{ Pharmacokinetics } \\
\hline & MW (g/mol) & ROTB (n) & $\operatorname{HBA}(\mathrm{n})$ & $\operatorname{HBD}(\mathrm{n})$ & TPSA $(\AA)$ & $C \log \mathrm{P}_{\mathrm{o} / \mathrm{w}}$ & GIA & BBBP \\
\hline Rule & $<500$ & $\leq 10$ & $<10$ & $<5$ & $\leq 140$ & $<5$ & - & - \\
\hline $\begin{array}{l}\text { FA } \\
(\mathbf{1})\end{array}$ & 194.18 & 3 & 4 & 2 & 66.76 & 1.36 & High & Yes \\
\hline 3 & 298.33 & 7 & 4 & 1 & 55.76 & 3.40 & High & Yes \\
\hline 4 & 300.35 & 8 & 4 & 1 & 55.76 & 3.13 & High & Yes \\
\hline 5 & 297.35 & 7 & 3 & 2 & 58.56 & 2.90 & High & Yes \\
\hline 8 & 286.32 & 7 & 4 & 1 & 55.76 & 2.95 & High & Yes \\
\hline 9 & 272.30 & 6 & 4 & 1 & 55.76 & 3.09 & High & Yes \\
\hline
\end{tabular}

Abbreviations: BBBP, blood-brain barrier permeation; CLog $\mathrm{P}_{\mathrm{o} / \mathrm{w}}$, logarithm of compound partition coefficient between $n$-octanol and water; GIA, gastrointestinal absorption; HBA, hydrogen bonds acceptors; HBD, hydrogen bond donors; MW, molecular weight; $n$, number; ROTB, rotatable bonds; TPSA, topological polar surface area.

\subsection{Molecular Docking}

A docking protocol was used to predict the possible interactions between $\mathrm{AChE}$ and $\mathrm{BChE}$ and the ligands reported in this study. Ligands with the lowest predicted binding energies were considered the most active compounds. The $\mathrm{AChE}$ and $\mathrm{BChE}$ crystals were selected for docking on their quality, ligand presence and use in literature [18-24]. For AChE, the selected proteins are: PDB: 4EY4 [25], PDB: 4EY7 [25]; PDB: 4BDT [26], and PDB: 4M0F [27]. For BChE selected proteins are: PDB: 1P0I [28]; PDB: 1P0M [28], and PDB: 6EQQ [29].

The docking results with AChE (PDB: 4EY4) and BChE (PDB:1P0I) are shown in Table 3. In general, the affinities of our molecules do not change much with all tested proteins.

Table 3. Acetylcholinesterase (AChE) and butyrylcholinesterase (BChE) docking affinity and interactions ${ }^{\mathrm{a}}$.

\begin{tabular}{|c|c|c|c|c|}
\hline & Ligand & $\begin{array}{c}\text { Affinity } \\
\text { (kcal/mol) }\end{array}$ & H-Bonds & $\pi-\pi$ Interactions \\
\hline \multirow{6}{*}{ 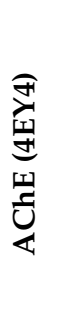 } & FA (1) & -7.5 & Asp74, Tyr337, Tyr341 & Trp86 \\
\hline & 3 & -9.2 & Trp286 & Trp86, Tyr337 \\
\hline & 4 & -10.2 & Gly121, Ser125, Ser203 & Trp86, Phe338, Tyr341 \\
\hline & 5 & -8.8 & Asp74, Trp286 × 2 & Trp86, Tyr337 \\
\hline & 8 & -9.7 & Tyr124, Ser125 & Trp86, Tyr337, Phe338 \\
\hline & 9 & -9.8 & Arg296 $\times 2$ & Trp286, Tyr337, Tyr341 \\
\hline \multirow{6}{*}{ 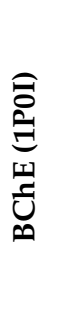 } & FA (1) & -6.8 & Asp70, Tyr128, Gly197, Tyr332 × 2 & $\operatorname{Trp} 82$ \\
\hline & 3 & -9.0 & Tyr128, Gly197 & Trp82, Tyr332 \\
\hline & 4 & -9.0 & Trp82, Tyr128, Tyr440 & Trp82, Tyr332 \\
\hline & 5 & -8.6 & Pro285, Ser198 × 2, His438 & Trp231, Phe329, Tyr332 \\
\hline & 8 & -8.7 & His438 & $\operatorname{Trp} 231, \operatorname{Trp} 329$ \\
\hline & 9 & -8.4 & Glu197 & Trp82, Tyr332 \\
\hline
\end{tabular}

a: docking results with all selected proteins are in the Supplementary Material Tables S1S-S5. 
The affinities do not change much across the tested crystals. All synthesized compounds presented the lowest predicted binding energy. As reference, the calculated binding energy of FA (1) is -7.5 and $-6.8 \mathrm{kcal} / \mathrm{mol}$ with $\mathrm{AChE}$ and $\mathrm{BChE}$, respectively. Among all compounds, derivative 4 has the best affinity results with $\mathrm{AChE}$ and $\mathrm{BChE}(-10.2,-9.0 \mathrm{kcal} / \mathrm{mol}$, respectively) (Table 3). Reducing the $\alpha-\beta$ unsaturation of compound 3, to obtain ester 4, appears to be beneficial for greater affinity with AChE. On the other hand, the reduction of this same unsaturation of compound 3 has no effect on the affinity of compound 4 for BChE. Compounds 3 and 4 have the same highest affinity for BChE (Table 3).

Overall, the synthesized derivatives have a noticeably higher affinity for AChE than BChE. With AChE catechol moieties of our ligands were around the middle of the gorge pointing towards the opening, while with $\mathrm{BChE}$ catechol moieties were near the end of the gorge pointing inside the gorge, some exceptions were noticed, for instance, compounds, 5, 9 and 4 had slightly different poses when comparing between proteins. Analogues 5 and 4 had slightly different poses in BChE. On the other hand, the catechol moiety of compound 8 in BChE pointed towards the opening of the gorge. On the contrary, the moiety pointed inside the cavity in the case of FA with AChE.

Several tested ligands had interactions with key residues. Most tested ligands seem to make a $\pi-\pi$ interaction with Trp86 (with AChE: Figure 2) or Trp82 (with BChE), which would place the ligands near or in the anionic sub-site [23,29], possibly blocking its activity. Ligands 5, 8 and 9 that do not have $\pi-\pi$ interactions with $\operatorname{Trp} 86$ or $\operatorname{Trp} 82$ but had $\pi-\pi$ interactions with Trp286 or Trp231 and Phe329 residues that are considered to be part of the anionic sub-site.
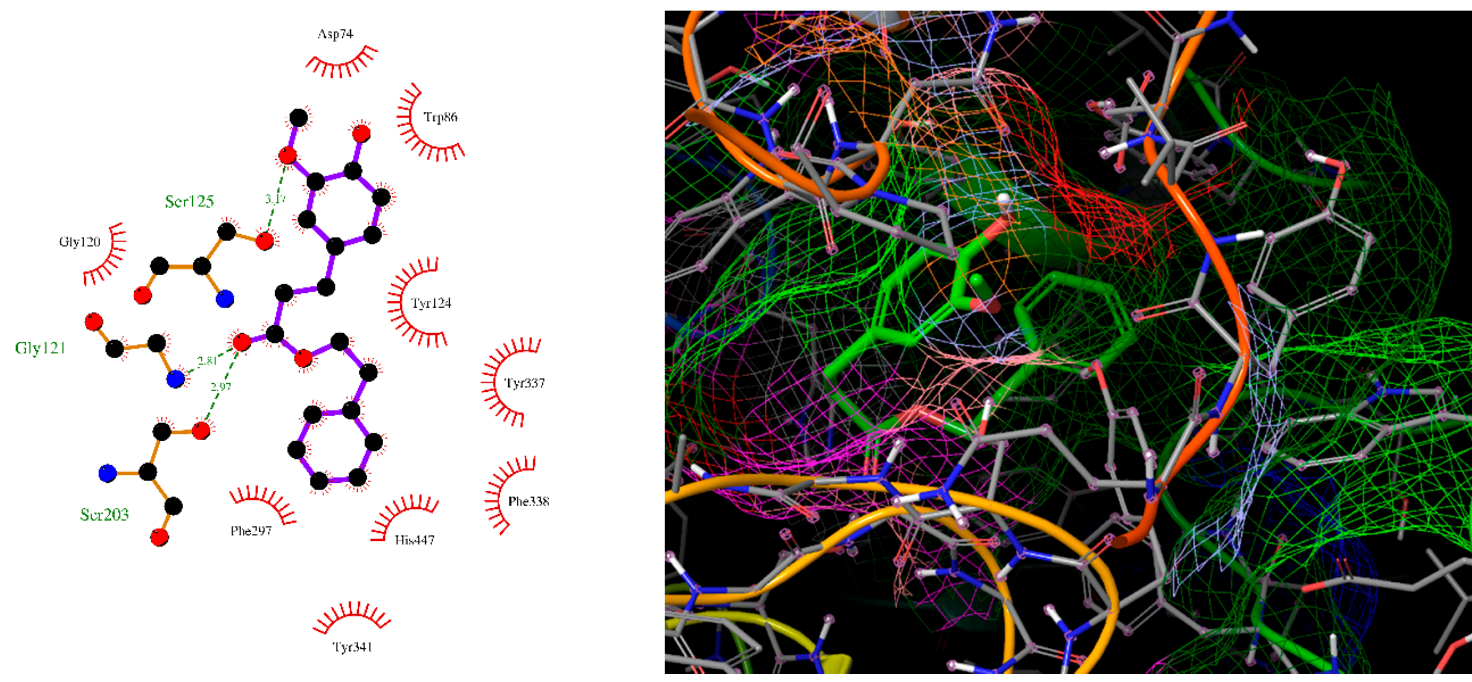

Figure 2. Hydroferulic acid phenethyl ester 4 with AChE (PDB: 4EY4) (left: Hydrogen bonds with Ligplot $^{+}$; right: 3D image with Maestro).

Interactions with Tyr337 residue, which are considered as "sweeping gates", were reported to be essential for AChE inhibition [29]. All compounds, except 4, have $\pi-\pi$ interactions with this residue. FA (1) has, a hydrogen bond with this residue. Interaction with Ala238, the equivalent residue of Tyr337, is not seen with BChE. On the other hand, FA (1) and 8 have a $\pi-\pi$ interaction with Tyr332 of BChE. This interaction may help binding with acetylcholine and may block the ligand movement inside the gorge [29]. Interaction with Tyr341, the equivalent residue of Tyr332, is not seen with AChE, except with FA (1), 4, and $\mathbf{9}$.

Among all docked compounds, ligands 4 and 8 showed interactions with the residues of the catalytic triad of $\mathrm{AChE}$ and $\mathrm{BChE}$. With these interactions and by being at the bottom of the gorge, ligands 4 and 8 are in an ideal position to block access to the catalytic triad of AChE and BChE, respectively. Coupled with their interactions with the anionic sub-site, ligands 4 and 8 may have potential as inhibitors of $\mathrm{AChE}$ and $\mathrm{BChE}$, respectively. 
As a control of our docking, a crystallized ligand was chosen and re-docked into the chosen AChE proteins. Donepezil, a piperidine derivative acetylcholinesterase inhibitor, was chosen as it has 3,4-dimethoxyphenyl moiety which can be similar to the catechol moiety of our derivatives. With AChE (PDB: 4EY7) the root mean square deviation (RMSD) of $\mathbf{3}, \mathbf{5}$ and $\mathbf{9}$ was 1.47, 1.60 and $2.94 \AA$, respectively, which superimpose the catechol moiety of donepezil with these ligands catechol while the rest of the molecule follows a similar path down the gorge.

\section{Materials and Methods}

\subsection{Chemistry}

All chemicals used were purchased from Aldrich (CA) and used without further purification. Purification of compounds was carried out by flash chromatography (Teledyne Isco, Inc. CombiFlash ${ }^{\mathrm{TM}}$ Sg100c, Lincoln, NE, USA). TLC was run on silica gel coated aluminum sheets (SiliaPlate TLC, Silicycle ${ }^{\circledR}$ ) with detection by UV light (254 nm, UVS-11, Mineralight ${ }^{\circledR}$ shortwave UV lamp, Upland, CA, USA). Melting points were obtained using a MELTEMP ${ }^{\circledR}$ (model 1001D) melting point apparatus. FTIR spectra were recorded on a Cary 630 spectrometer. NMR spectra were recorded on a Bruker ${ }^{\circledR}$ Avance III $400 \mathrm{MHz}$ spectrometer using TMS as an internal standard. High-resolution mass measurements were performed on a Bruker $囚 D o l t o n i c s '$ micrOTOF instrument in positive or negative electrospray $\left({ }^{1} \mathrm{H}-\mathrm{NMR}, \mathrm{FTIR},{ }^{13} \mathrm{C}-\mathrm{NMR}\right.$, and HRMS spectra: see Supplementary Materials, pages S2-S31).

\subsubsection{General Procedure for the Esterification of Phenolic Acids.}

To a vigorously stirred solution of $\mathrm{Na}_{2} \mathrm{CO}_{3}$ (1.2 eq) in $6 \mathrm{~mL}$ of DMSO, the appropriate phenolic acid ( 1 eq) is added after which the reaction vessel is put under argon atmosphere. After 30 min of stirring, the appropriate bromide (1.1 eq) is dissolved in $1 \mathrm{~mL}$ of DMSO and added dropwise to the reaction mixture over a period of $30 \mathrm{~min}$. A small amount of $\mathrm{KI}$ is added and the reaction vessel is thoroughly flushed with argon gas and sealed under balloon pressure. The reaction mixture is stirred in an ice bath for $30 \mathrm{~min}$ and at room temperature for $24 \mathrm{~h}$ under argon atmosphere. The resulting solution is quenched with $30 \mathrm{~mL}$ of ice water and stirred for $30 \mathrm{~min}$. The aqueous phase was extracted three times with AcOEt $(30 \mathrm{~mL})$. The organic fractions are then combined, washed with brine, dried over $\mathrm{MgSO}_{4}$ and concentrated. The resulting oil is purified by flash chromatography.

2-Phenylethyl (2E)-3-(4-hydroxy-3-methoxyphenyl)prop-2-enoate (3)

Following our single step esterification procedure with ferulic acid (1) $(500 \mathrm{mg}, 2.57 \mathrm{mmol}$, $1 \mathrm{eq}), \mathrm{Na}_{2} \mathrm{CO}_{3}(410 \mathrm{mg}, 3.86 \mathrm{mmol}, 1.5 \mathrm{eq})$ and 2-phenylethyl bromide $(0.397 \mathrm{~mL}, 3.08 \mathrm{mmol}$, $1.2 \mathrm{eq})$, compound 3 was obtained as a colourless oil after flash chromatography (0-10\% AcOEt/Hex), yield $=78 \%$, Rf $=0.43$ (30\% AcOEt/Hex). FTIR: 3600-3100, 2847, and $1714 \mathrm{~cm}^{-1} ;{ }^{1} \mathrm{H}$ NMR (DMSO- $d_{6}$, $\left.25^{\circ} \mathrm{C}\right) ; \delta(\mathrm{ppm})=9.61(\mathrm{~s}, 1 \mathrm{H}, \mathrm{OH}), 7.53\left(\mathrm{~d}, 1 \mathrm{H}, J=15.9 \mathrm{~Hz}, \mathrm{C}_{\mathrm{Ar}}-\mathrm{CH}=\mathrm{CH}\right), 7.34-7.29\left(\mathrm{~m}, 5 \mathrm{H}, \mathrm{H}_{\mathrm{Ar}}\right)$, $7.25-7.21\left(\mathrm{~m}, 1 \mathrm{H}, \mathrm{H}_{\mathrm{Ar}}\right), 7.10\left(\mathrm{dd}, 1 \mathrm{H}, J=1.8,8.2 \mathrm{~Hz}, \mathrm{H}_{\mathrm{Ar}}\right), 6.79\left(\mathrm{~d}, 1 \mathrm{H}, J=8.1 \mathrm{~Hz}, \mathrm{H}_{\mathrm{Ar}}\right), 6.45(\mathrm{~d}, 1 \mathrm{H}$, $J=15.9 \mathrm{~Hz}, \mathrm{CH}=\mathrm{CH}-\mathrm{C}(=\mathrm{O})), 4.35\left(\mathrm{t}, 2 \mathrm{H}, J=6.8 \mathrm{~Hz}, \mathrm{CH}_{2} \mathrm{O}\right), 3.82\left(\mathrm{~s}, 3 \mathrm{H}, \mathrm{OCH}_{3}\right), 2.97(\mathrm{t}, 2 \mathrm{H}, J=6.8 \mathrm{~Hz}$, $\left.\mathrm{CH}_{2} \mathrm{Ph}\right) ;{ }^{13} \mathrm{C}$ NMR (DMSO- $\left.d_{6}, 25^{\circ} \mathrm{C}\right) ; \delta(\mathrm{ppm})=167.06,149.86,148.64,145.64,138.56,129.32,128.85$, $126.83,125.99,123.73,115.94,114.77,111.63,64.74,56.17,34.95$; HRMS $m / z$ calc. for $\mathrm{C}_{18} \mathrm{H}_{18} \mathrm{O}_{4}+\left(\mathrm{H}^{+}\right)$: 299.1278; found: 299.1272 .

Phenethyl 3-(4-hydroxy-3-methoxyphenyl)propanoate (4)

Compound 3 (152 mg, $0.53 \mathrm{mmol}$ ) was dissolved in $\mathrm{MeOH}(10 \mathrm{~mL})$ and 10\% Pd/C (16 mg) was added. The flask was sealed with a rubber septum and positive pressure of $\mathrm{H}_{2}$ was maintained by a balloon attached via a syringe needle at room temperature. The progress of the reaction was monitored by TLC until the complete conversion after $16 \mathrm{~h}$. The reaction mixture was filtered through celite and the solvent was removed under reduced pressure to give pure 4 (150 $\mathrm{mg}$, quantitative yield) of a 
colourless oil. Yield $=95 \%$, Rf $=0.22\left(10 \%\right.$ AcOEt/Hex). FTIR: 3550-3200, 2935, and $1731 \mathrm{~cm}^{-1} ;{ }^{1} \mathrm{H} \mathrm{NMR}$ $\left(400 \mathrm{MHz}, \mathrm{CDCl}_{3}, 25^{\circ} \mathrm{C}\right), \delta(\mathrm{ppm})=7.33-7.20\left(\mathrm{~m}, 5 \mathrm{H}, \mathrm{H}_{\mathrm{ar}}\right), 7.25-7.21\left(\mathrm{~m}, 3 \mathrm{H}, \mathrm{H}_{\mathrm{ar}}\right), 6.84(\mathrm{~d}, 1 \mathrm{H}, J=7.9$ $\left.\mathrm{Hz}, \mathrm{H}_{\mathrm{ar}}\right), 6.71-6.67\left(\mathrm{~m}, 2 \mathrm{H}, \mathrm{H}_{\mathrm{ar}}\right), 5.51(\mathrm{~s}, 1 \mathrm{H}, \mathrm{ArOH}), 4.31\left(\mathrm{t}, 2 \mathrm{H}, J=7 \mathrm{~Hz},-\mathrm{COOCH}_{2} \mathrm{CH}_{2} \mathrm{Ar}\right), 3.88(\mathrm{~s}, 3 \mathrm{H}$, $\left.\mathrm{ArOCH}_{3}\right), 2.93\left(\mathrm{t}, 2 \mathrm{H}, J=7 \mathrm{~Hz},-\mathrm{CH}_{2} \mathrm{CH}_{2} \mathrm{COOCH}_{2} \mathrm{CH}_{2} \mathrm{Ar}\right), 2.88\left(\mathrm{t}, 2 \mathrm{H}, J=7.7 \mathrm{~Hz},-\mathrm{COOCH}_{2} \mathrm{CH}_{2} \mathrm{Ar}\right)$, 2.62-2.58 (m, $\left.2 \mathrm{H},-\mathrm{CH}_{2} \mathrm{CH}_{2} \mathrm{COOCH}_{2} \mathrm{CH}_{2} \mathrm{Ar}\right) ;{ }^{13} \mathrm{C} \mathrm{NMR}\left(100 \mathrm{MHz}, \mathrm{CDCl}_{3}, 25^{\circ} \mathrm{C}\right), \delta(\mathrm{ppm})=172.91$, 146.40, 144.03, 137.81, 132.45, 128.89, 128.49, 126.57, 120.85, 114.32, 110.91, 64.94, 55.86, 36.30, 35.11, 30.66. HRMS $m / z$ calc. for $\mathrm{C}_{18} \mathrm{H}_{20} \mathrm{O}_{4}+\left(\mathrm{H}^{+}\right)$: 283.1329; found: 283.1322 .

3-(4-Hydroxy-3-methoxyphenyl)-N-phenethylacrylamide (5)

Ferulic acid (1) (250 mg, $1.28 \mathrm{mmol}, 1 \mathrm{eq})$ and phenethyl amine $(0.196 \mathrm{~mL}, 1.53 \mathrm{mmol}, 1.2 \mathrm{eq})$, were dissolved in dry $\mathrm{CH}_{2} \mathrm{Cl}_{2}(10 \mathrm{~mL})$. BOP $(684 \mathrm{mg}, 1.53 \mathrm{mmol}, 1.2 \mathrm{eq})$ and $\mathrm{Et}_{3} \mathrm{~N}(0.180 \mathrm{~mL}, 1.28 \mathrm{mmol}$, $1 \mathrm{eq}$ ) were added to the mixture. After stirring for $16 \mathrm{~h}$ at rt the solution was diluted with $\mathrm{CH}_{2} \mathrm{Cl}_{2}$ and the organic layer washed with saturated $\mathrm{NaHCO}_{3}$ solution, water, and brine. After drying $\left(\mathrm{MgSO}_{4}\right)$ and concentration, compound $\mathbf{5}$ was obtained as a pale-yellow solid after flash chromatography $(0-20 \%$ AcOEt $/$ Hex $)$, yield $=69 \%, \mathrm{Rf}=0.22(10 \% \mathrm{AcOEt} / \mathrm{Hex}), \mathrm{mp}=142-143^{\circ} \mathrm{C}$. FTIR: $3300-3200,2931$, and $1653 \mathrm{~cm}^{-1} ;{ }^{1} \mathrm{H}$ NMR $\left(400 \mathrm{MHz}, \mathrm{CDCl}_{3}, 25^{\circ} \mathrm{C}\right), \delta(\mathrm{ppm})=7.56(\mathrm{~d}, 1 \mathrm{H}, J=15.5 \mathrm{~Hz}, \mathrm{ArCH}=\mathrm{CH}-)$, 7.36-7.33 (m, 2H, $\left.\mathrm{H}_{\mathrm{ar}}\right), 7.28-7.24\left(\mathrm{~m}, 3 \mathrm{H}, \mathrm{H}_{\mathrm{ar}}\right), 7.05\left(\mathrm{~d}, 1 \mathrm{H}, J=1.7 \mathrm{~Hz}, \mathrm{H}_{\mathrm{ar}}\right), 6.99(\mathrm{~d}, 1 \mathrm{H}, J=1.7 \mathrm{~Hz}$, $\left.\mathrm{H}_{\mathrm{ar}}\right), 6.91\left(\mathrm{~d}, 1 \mathrm{H}, J=8.2 \mathrm{~Hz}, \mathrm{H}_{\mathrm{ar}}\right), 6.20(\mathrm{~d}, 1 \mathrm{H}, J=15.5 \mathrm{~Hz}, \mathrm{ArCH}=\mathrm{CH}-), 5.94(\mathrm{~s}, 1 \mathrm{H}, \mathrm{ArOH}), 5.63(\mathrm{~s}$, $1 \mathrm{H},-\mathrm{CONH}), 3.91\left(\mathrm{~s}, 3 \mathrm{H}, \mathrm{ArOCH}_{3}\right), 3.71-3.66\left(\mathrm{~m}, 2 \mathrm{H},-\mathrm{CONHCH}_{2} \mathrm{CH}_{2} \mathrm{Ar}\right) ; 2.90(\mathrm{t}, 2 \mathrm{H}, J=6.7 \mathrm{~Hz}$, $\left.-\mathrm{CONHCH}_{2} \mathrm{CH}_{2} \mathrm{AR}\right) ;{ }^{13} \mathrm{C}$ NMR $\left(100 \mathrm{MHz}, \mathrm{CDCl}_{3}, 25^{\circ} \mathrm{C}\right), \delta(\mathrm{ppm})=166.17,147.41,146.72,141.09$, $138.94,128.83,128.69,127.33,126.55,122.13,118.14,114.72,109.61,55.92,40.74,35.70$. HRMS $\mathrm{m} / \mathrm{z}$ calc. for $\mathrm{C}_{18} \mathrm{H}_{19} \mathrm{NO}_{3}+\left(\mathrm{H}^{+}\right)$: 298.1438; found: 298.1437 .

Phenethyl 2-(4-hydroxy-3-methoxyphenyl)acetate (8)

Following our single step esterification procedure with homovanillic acid (6) ( $250 \mathrm{mg}, 1.37 \mathrm{mmol}$, $1 \mathrm{eq}), \mathrm{Na}_{2} \mathrm{CO}_{3}$ (218 mg, $\left.2.05 \mathrm{mmol}, 1.5 \mathrm{eq}\right)$ and 2-phenylethyl bromide $(0.225 \mathrm{~mL}, 2.05 \mathrm{mmol}, 1.2 \mathrm{eq})$, compound 8 was obtained as a pale yellow oil after flash chromatography $(0-10 \% \mathrm{AcOEt} / \mathrm{Hex})$, yield $=80 \%$, Rf $=0.18(10 \%$ AcOEt/Hex $)$. FTIR: 3600-3200, 2845, and $1729 \mathrm{~cm}^{-1} ;{ }^{1} \mathrm{H} \mathrm{NMR}(400 \mathrm{MHz}$, $\left.\mathrm{CDCl}_{3}, 25^{\circ} \mathrm{C}\right), \delta(\mathrm{ppm})=7.31-7.22\left(\mathrm{~m}, 3 \mathrm{H}, \mathrm{H}_{\mathrm{ar}}\right), 7.18-7.16\left(\mathrm{~m}, 2 \mathrm{H}, \mathrm{H}_{\mathrm{ar}}\right), 6.87\left(\mathrm{~d}, 1 \mathrm{H}, J=7.9 \mathrm{~Hz}, \mathrm{H}_{\mathrm{ar}}\right)$, 6.77-6.74 (m, 2H, $\left.\mathrm{H}_{\mathrm{ar}}\right), 5.58(\mathrm{~s}, 1 \mathrm{H}, \mathrm{ArOH}), 4.33\left(\mathrm{t}, 2 \mathrm{H}, J=6.9 \mathrm{~Hz},-\mathrm{COOCH}_{2} \mathrm{CH}_{2} \mathrm{Ar}\right), 3.87(\mathrm{~s}, 3 \mathrm{H}$, $\left.\mathrm{ArOCH}_{3}\right), 3.54\left(\mathrm{~s}, 2 \mathrm{H},-\mathrm{CH}_{2} \mathrm{COOCH}_{2} \mathrm{CH}_{2} \mathrm{Ar}\right), 2.94\left(\mathrm{t}, 2 \mathrm{H}, J=6.9 \mathrm{~Hz},-\mathrm{COOCH}_{2} \mathrm{CH}_{2} \mathrm{Ar}\right) ;{ }^{13} \mathrm{C} \mathrm{NMR}$ $\left(100 \mathrm{MHz}, \mathrm{CDCl}_{3}, 25^{\circ} \mathrm{C}\right), \delta(\mathrm{ppm})=171.81,146.45,144.75,137.76,128.90,128.45,126.52,125.76,122.17$, 114.34, 11.72, 65.28, 55.89, 41.06, 35.05; HRMS $m / z$ calc. for $\mathrm{C}_{17} \mathrm{H}_{18} \mathrm{O}_{4}+\left(\mathrm{H}^{+}\right)$: 287.1278; found: 287.127.

Phenethyl 4-hydroxy-3-methoxybenzoate (9)

Following our single step esterification procedure with vanillic acid (7) $(500 \mathrm{mg}, 2.97 \mathrm{mmol}$, 1 eq), $\mathrm{Na}_{2} \mathrm{CO}_{3}$ (472 mg, $\left.4.45 \mathrm{mmol}, 1.5 \mathrm{eq}\right)$ and 2-phenylethyl bromide $(0.478 \mathrm{~mL}, 3.56 \mathrm{mmol}, 1.2 \mathrm{eq})$, compound 9 was obtained as a pale yellow oil after flash chromatography $(0-10 \%$ AcOEt/Hex), yield $=83 \%, \mathrm{Rf}=0.18(10 \%$ AcOEt/Hex $)$. FTIR: 3600-3300, 2850, and $1717 \mathrm{~cm}^{-1} ;{ }^{1} \mathrm{H}$ NMR $(400 \mathrm{MHz}$, $\left.\mathrm{CDCl}_{3}, 25^{\circ} \mathrm{C}\right), \delta(\mathrm{ppm})=7.63-\left(\mathrm{d}, 1 \mathrm{H}, \mathrm{J}=1.8 \mathrm{~Hz}, \mathrm{H}_{\mathrm{ar}}\right), 7.53\left(\mathrm{~d}, 1 \mathrm{H}, J=1.8 \mathrm{~Hz}, \mathrm{H}_{\mathrm{ar}}\right), 7.36-7.24(\mathrm{~m}, 5 \mathrm{H}$, $\left.\mathrm{H}_{\mathrm{ar}}\right), 6.95\left(\mathrm{~d}, 1 \mathrm{H}, J=8.3 \mathrm{~Hz}, \mathrm{H}_{\mathrm{ar}}\right), 6.04-6.03(\mathrm{~m}, 1 \mathrm{H}, \mathrm{ArOH}), 4.52\left(\mathrm{t}, 2 \mathrm{H}, J=7 \mathrm{~Hz},-\mathrm{COOCH}_{2} \mathrm{CH}_{2} \mathrm{Ar}\right)$, $3.95\left(\mathrm{~s}, 3 \mathrm{H}, \mathrm{ArOCH}_{3}\right), 3.09\left(\mathrm{t}, 2 \mathrm{H}, J=6.9 \mathrm{~Hz},-\mathrm{COOCH}_{2} \mathrm{CH}_{2} \mathrm{Ar}\right) ;{ }^{13} \mathrm{C} \mathrm{NMR}\left(100 \mathrm{MHz}, \mathrm{CDCl}_{3}, 25^{\circ} \mathrm{C}\right)$, $\delta(\mathrm{ppm})=166.28,150.01,146.13,138.04,129.00,128.52,126.57,124.16,122.42,114.06,11.73,65.30,56.07$, 35.32. HRMS $m / z$ calc. for $\mathrm{C}_{16} \mathrm{H}_{16} \mathrm{O}_{4}+\left(\mathrm{H}^{+}\right)$: 273.1121; found: 273.1113 .

\subsection{Free Radical Scavenging Activity Assay}

The free radical scavenging activity of test compounds was measured as previously described using 2,2-diphenyl-1-picrylhydrazyl (DPPH) as a stable radical (Touaibia et al., 2018) with slight modifications. DPPH $(200 \mu \mathrm{L})$ in ethanol $(250 \mu \mathrm{M})$ was mixed with $200 \mu \mathrm{L}$ of the test compounds (1, $5,10,25,50,75$ and $100 \mu \mathrm{g} / \mathrm{mL})$. Each mixture was then shaken vigorously and held in the dark for 
$30 \mathrm{~min}$ at room temperature. The absorbance of DPPH at $517 \mathrm{~nm}$ was then measured. The radical scavenging activity was expressed in terms of \% inhibition of DPPH absorbance:

$$
\% \text { Inhibition }=(\text { A control }-\mathrm{A} \text { test }) / \text { control }) \times 100
$$

where A control is the absorbance of the control (DPPH solution without test compounds) and A test is the absorbance of the test sample (DPPH solution plus compounds). Ascorbic acid was used as a positive control. Data were expressed as mean \pm SEM of three independent experiments, each performed in triplicate. $\mathrm{IC}_{50}$ values were calculated from a sigmoidal concentration-response curve-fitting model with a variable slope on GraphPad Prism software.

\subsection{Molecular Docking}

Autodock Vina [30] was used with the help of Autodock Tools (ADT) [31] to prepare the ligands and proteins. A standard docking protocol was followed. Details and changes are listed in the following text. For preparation, the selected proteins were aligned with 4EY4 to have similar docking settings across all 7 proteins and to help compare the results. The proteins were also cleaned up-only chain A was kept, polar hydrogens were added, any ligands or molecules and water molecules were deleted. For 6EQQ, Ile111 and Thr512 were corrected with ADT. Both residues are far from the active site, therefore, no problem should be expected from this correction. The deletion of water molecules may have a slight impact on the results obtained. Some studies $[29,32,33]$ show that it may and can play an important role in the binding of some ligands in the active site. However, the removal of water is part of the standard protocol with Autodock Vina and is used by many studies [22,34]. For both $\mathrm{AChE}$ and $\mathrm{BChE}$, flexibility of certain residues in and around the gorge was chosen based on literature $[25,29,35]$, visual observation and comparison of the RMSD values on a per residue basis. To get a larger pool of data for visual and RMSD comparison, all available crystal structures with a 100\% sequence similarity was used. Slightly different settings were chosen for AChE and BChE. For AChE, the size of the grid was $(27,31,22)$ in $(x, y, z)$ axis respectively, the center point was $(-14.2$, $-45.79,27.55)$ while for $\mathrm{BChE}$ the grid was $(27,31,24)$ and the center point was $(-14.2,-46.79,27.55)$. In both cases, the chosen "exhaustiveness" was " 20 ". The most stable pose was chosen for analysis, Ligplot $^{+}$[36] and Maestro [37] were used for visualization.

\section{Conclusions}

Phenethyl esters obtained through our single step esterification as well as the amide analog show good free radical-scavenging activities. All compounds obey Lipinski's rules and are predicted to cross the BBB which is crucial for AD drug candidates. The molecular docking of analogues 4 and 8 with $\mathrm{AChE}$ and $\mathrm{BChE}$ showed interesting interactions with the residues of the catalytic triad or the anionic sub-site. Combining the latter two interactions, hydroferulic acid phenethyl ester $\mathbf{4}$ and homovanilic acid phenethyl ester 8 can be good candidates as potential AChE and BChE inhibitors.

Supplementary Materials: The following are available online. ${ }^{1} \mathrm{H}-\mathrm{NMR}$, FTIR, ${ }^{13} \mathrm{C}-\mathrm{NMR}$, and HRMS spectra (Pages S2-S31); Docking results with selected acetylcholinesterases and butyrylcholinesterases (Table S1-S5).

Author Contributions: Conceptualization, M.T.; methodology, A.S., F.J.N.M., M.C., and M.T.; formal analysis, A.S., F.J.N.M., M.C., and M.T.; investigation, A.S., F.J.N.M., M.C., and M.T.; writing-original draft preparation, A.S., F.J.N.M., M.C., and M.T.; writing-review and editing, A.S. and M.T.; visualization, M.T.; supervision, M.T. All authors have read and agreed to the published version of the manuscript.

Funding: This research received funding from Natural Sciences and Engineering Research Council of Canada (NSERC).

Conflicts of Interest: The authors declare no conflict of interest. 


\section{References}

1. Dassel, K.; Butler, J.; Telonidis, J.; Edelman, L. Development and evaluation of Alzheimer's Disease and Related Dementias (ADRD) best care practices in long-term care online training program. Educ. Gerontol. 2020, 46, 150-157. [CrossRef]

2. Wan, T.; Wang, Z.; Luo, Y.; Zhang, Y.; He, W.; Mei, Y.; Xue, J.; Li, M.; Pan, H.; Li, W.; et al. FA-97, a New Synthetic Caffeic Acid Phenethyl Ester Derivative, Protects against Oxidative Stress-Mediated Neuronal Cell Apoptosis and Scopolamine-Induced Cognitive Impairment by Activating Nrf2/HO-1 Signaling. Oxidative Med. Cell. Longev. 2019, 2019, 8239642. [CrossRef] [PubMed]

3. Sharma, P.; Srivastava, P.; Seth, A.; Tripathi, P.N.; Banerjee, A.G.; Shrivastava, S.K. Comprehensive review of mechanisms of pathogenesis involved in Alzheimer's disease and potential therapeutic strategies. Prog. Neurobiol. 2019, 174, 53-89. [CrossRef] [PubMed]

4. Morroni, F.; Sita, G.; Graziosi, A.; Turrini, E.; Fimognari, C.; Tarozzi, A.; Hrelia, P. Neuroprotective Effect of Caffeic Acid Phenethyl Ester in A Mouse Model of Alzheimer's Disease Involves Nrf2/HO-1 Pathway. Aging Dis. 2018, 9, 605-622. [CrossRef]

5. Cai, Z.; Zhao, B.; Ratka, A. Oxidative Stress and $\beta$-Amyloid Protein in Alzheimer's Disease. Neuromol. Med. 2011, 13, 223-250. [CrossRef]

6. Inestrosa, N.C.; Dinamarca, M.C.; Alvarez, A. Amyloid-cholinesterase interactions. FEBS J. 2008, 275, 625-632. [CrossRef] [PubMed]

7. Digiacomo, M.; Chen, Z.; Wang, S.; Lapucci, A.; Macchia, M.; Yang, X.; Chu, J.; Han, Y.; Pi, R.; Rapposelli, S. Synthesis and pharmacological evaluation of multifunctional tacrine derivatives against several disease pathways of AD. Bioorg. Med. Chem. Lett. 2015, 25, 807-810. [CrossRef] [PubMed]

8. Bachurin, S.O.; Bovina, E.V.; Ustyugov, A.A. Drugs in Clinical Trials for Alzheimer's Disease: The Major Trends. Med. Res. Rev. 2017, 37, 1186-1225. [CrossRef] [PubMed]

9. Benchekroun, M.; Pachón-Angona, I.; Luzet, V.; Martin, H.; Oset-Gasque, M.-J.; Marco-Contelles, J.; Ismaili, L. Synthesis, antioxidant and $\mathrm{A} \beta$ anti-aggregation properties of new ferulic, caffeic and lipoic acid derivatives obtained by the Ugi four-component reaction. Bioorg. Chem. 2019, 85, 221-228. [CrossRef] [PubMed]

10. He, X.-x.; Yang, X.-h.; Ou, R.-y.; Ouyang, Y.; Wang, S.-n.; Chen, Z.-w.; Wen, S.-j.; Pi, R.-b. Synthesis and evaluation of multifunctional ferulic and caffeic acid dimers for Alzheimer's disease. Nat. Prod. Res. 2017, 31, 734-737. [CrossRef] [PubMed]

11. Kumar, N.; Pruthi, V. Potential applications of ferulic acid from natural sources. Biotechnol. Rep. 2014, 4, 86-93. [CrossRef] [PubMed]

12. Kim, H.-S.; Cho, J.-y.; Kim, D.-H.; Yan, J.-J.; Lee, H.-K.; Suh, H.-W.; Song, D.-K. Inhibitory Effects of Long-Term Administration of Ferulic Acid on Microglial Activation Induced by Intracerebroventricular Injection of ß-Amyloid Peptide (1-42) in Mice. Biol. Pharm. Bull. 2004, 27, 120-121. [CrossRef] [PubMed]

13. Kumar, M.; Kaur, D.; Bansal, N. Caffeic Acid Phenethyl Ester (CAPE) Prevents Development of STZ-ICV Induced dementia in Rats. Pharm. Mag 2017, 13, S10-S15.

14. DeBay, D.R.; Reid, G.A.; Macdonald, I.R.; Mawko, G.; Burrell, S.; Martin, E.; Bowen, C.V.; Darvesh, S. Butyrylcholinesterase-knockout reduces fibrillar $\beta$-amyloid and conserves 18FDG retention in 5XFAD mouse model of Alzheimer's disease. Brain Res. 2017, 1671, 102-110. [CrossRef]

15. Appendino, G.; Minassi, A.; Daddario, N.; Bianchi, F.; Tron, G.C. Chemoselective Esterification of Phenolic Acids and Alcohols. Org. Lett. 2002, 4, 3839-3841. [CrossRef]

16. Shi, Z.-H.; Li, N.-G.; Shi, Q.-P.; Hao, T.; Tang, Y.-P.; Wei, L.; Lian, Y.; Yang, J.-P.; Duan, J.-A. Design, Synthesis and Biological Evaluation of Ferulic Acid Amides as Selective Matrix Metalloproteinase Inhibitors. Med. Chem. 2013, 9, 947-954.

17. Padurariu, M.; Ciobica, A.; Lefter, R.; Lacramioara Serban, I.; Stefanescu, C.; Chirita, R. The oxidative stress hypothesis in Alzheimer's disease. Psychiatr. Danub. 2013, 25, 401-409.

18. Parveen, M.; Aslam, A.; Nami, S.A.A.; Malla, A.M.; Alam, M.; Lee, D.-U.; Rehman, S.; Silva, P.S.P.; Silva, M.R. Potent acetylcholinesterase inhibitors: Synthesis, biological assay and docking study of nitro acridone derivatives. J. Photochem. Photobiol. B Biol. 2016, 161, 304-311. [CrossRef]

19. Dighe, S.N.; Deora, G.S.; De la Mora, E.; Nachon, F.; Chan, S.; Parat, M.-O.; Brazzolotto, X.; Ross, B.P. Discovery and Structure-Activity Relationships of a Highly Selective Butyrylcholinesterase Inhibitor by Structure-Based Virtual Screening. J. Med. Chem. 2016, 59, 7683-7689. 
20. Lee, S.; Barron, M.G. Development of 3D-QSAR Model for Acetylcholinesterase Inhibitors Using a Combination of Fingerprint, Molecular Docking, and Structure-Based Pharmacophore Approaches. Toxicol. Sci. 2015, 148, 60-70. [CrossRef]

21. Ambure, P.; Kar, S.; Roy, K. Pharmacophore mapping-based virtual screening followed by molecular docking studies in search of potential acetylcholinesterase inhibitors as anti-Alzheimer's agents. Biosystems 2014, 116, 10-20. [CrossRef] [PubMed]

22. Hamulakova, S.; Janovec, L.; Hrabinova, M.; Spilovska, K.; Korabecny, J.; Kristian, P.; Kuca, K.; Imrich, J. Synthesis and Biological Evaluation of Novel Tacrine Derivatives and Tacrine-Coumarin Hybrids as Cholinesterase Inhibitors. J. Med. Chem. 2014, 57, 7073-7084. [CrossRef] [PubMed]

23. Cappelli, A.; Gallelli, A.; Manini, M.; Anzini, M.; Mennuni, L.; Makovec, F.; Menziani, M.C.; Alcaro, S.; Ortuso, F.; Vomero, S. Further Studies on the Interaction of the 5-Hydroxytryptamine3 (5-HT3) Receptor with Arylpiperazine Ligands. Development of a New 5-HT3 Receptor Ligand Showing Potent Acetylcholinesterase Inhibitory Properties. J. Med. Chem. 2005, 48, 3564-3575. [CrossRef] [PubMed]

24. Brus, B.; Košak, U.; Turk, S.; Pišlar, A.; Coquelle, N.; Kos, J.; Stojan, J.; Colletier, J.-P.; Gobec, S. Discovery, Biological Evaluation, and Crystal Structure of a Novel Nanomolar Selective Butyrylcholinesterase Inhibitor. J. Med. Chem. 2014, 57, 8167-8179. [CrossRef]

25. Cheung, J.; Rudolph, M.J.; Burshteyn, F.; Cassidy, M.S.; Gary, E.N.; Love, J.; Franklin, M.C.; Height, J.J. Structures of Human Acetylcholinesterase in Complex with Pharmacologically Important Ligands. J. Med. Chem. 2012, 55, 10282-10286.

26. Nachon, F.; Carletti, E.; Ronco, C.; Trovaslet, M.; Nicolet, Y.; Jean, L.; Renard, P.-Y. Crystal structures of human cholinesterases in complex with huprine W and tacrine: Elements of specificity for anti-Alzheimer's drugs targeting acetyl- and butyryl-cholinesterase. Biochem. J. 2013, 453, 393-399. [CrossRef]

27. Cheung, J.; Gary, E.N.; Shiomi, K.; Rosenberry, T.L. Structures of Human Acetylcholinesterase Bound to Dihydrotanshinone I and Territrem B Show Peripheral Site Flexibility. ACS Med. Chem. Lett. 2013, 4, 1091-1096. [CrossRef]

28. Nicolet, Y.; Lockridge, O.; Masson, P.; Fontecilla-Camps, J.C.; Nachon, F. Crystal Structure of Human Butyrylcholinesterase and of Its Complexes with Substrate and Products. J. Biol. Chem. 2003, 278, 41141-41147. [CrossRef]

29. Rosenberry, T.L.; Brazzolotto, X.; Macdonald, I.R.; Wandhammer, M.; Trovaslet-Leroy, M.; Darvesh, S.; Nachon, F. Comparison of the binding of reversible inhibitors to human butyrylcholinesterase and acetylcholinesterase: A crystallographic, kinetic and calorimetric study. Molecules 2017, 22, 2098. [CrossRef]

30. Trott, O.; Olson, A.J. AutoDock Vina: Improving the speed and accuracy of docking with a new scoring function, efficient optimization, and multithreading. J. Comput. Chem. 2010, 31, 455-461. [CrossRef]

31. Morris, G.M.; Huey, R.; Lindstrom, W.; Sanner, M.F.; Belew, R.K.; Goodsell, D.S.; Olson, A.J. AutoDock4 and AutoDockTools4: Automated docking with selective receptor flexibility. J. Comput. Chem. 2009, 30, 2785-2791. [CrossRef] [PubMed]

32. Kryger, G.; Silman, I.; Sussman, J.L. Structure of acetylcholinesterase complexed with E2020 (Ariceptß): Implications for the design of new anti-Alzheimer drugs. Structure 1999, 7, 297-307. [CrossRef]

33. Kryger, G.; Harel, M.; Giles, K.; Toker, L.; Velan, B.; Lazar, A.; Kronman, C.; Barak, D.; Ariel, N.; Shafferman, A.; et al. Structures of recombinant native and E202Q mutant human acetylcholinesterase complexed with the snake-venom toxin fasciculin-II. Acta Crystallogr. Sect. D 2000, 56, 1385-1394. [CrossRef] [PubMed]

34. Chiou, S.-Y.; Weng, T.-T.; Lin, G.-Z.; Lu, R.-J.; Jian, S.-Y.; Lin, G. Molecular docking of different inhibitors and activators to butyrylcholinesterase. J. Biomol. Struct. Dyn. 2015, 33, 563-572. [CrossRef] [PubMed]

35. Franklin, M.C.; Rudolph, M.J.; Ginter, C.; Cassidy, M.S.; Cheung, J. Structures of paraoxon-inhibited human acetylcholinesterase reveal perturbations of the acyl loop and the dimer interface. Proteins Struct. Funct. Bioinform. 2016, 84, 1246-1256. [CrossRef]

36. Laskowski, R.A.; Swindells, M.B. LigPlot+: Multiple Ligand-Protein Interaction Diagrams for Drug Discovery. J. Chem. Inf. Modeling 2011, 51, 2778-2786. [CrossRef]

37. Schrödinger. Schrödinger Maestro, Release, 2016-3; Schrödinger Inc.: New York, NY, USA, 2016.

(C) 2020 by the authors. Licensee MDPI, Basel, Switzerland. This article is an open access article distributed under the terms and conditions of the Creative Commons Attribution (CC BY) license (http://creativecommons.org/licenses/by/4.0/). 